\title{
PERANCANGAN PERHIASAN BERBAHAN PEWTER
}

\author{
Budi Hartono ${ }^{1}$ (budibawor@gmail.com, Jurusan Kriya Fakultas Seni Rupa Institut Seni Indonesia Yogyakarta)
}

\begin{abstract}
The use of tin as natural wealth in Indonesia for jewelry is not well known. White tin mixed with copper and antimony metal turns out to be a material that is visually appealing. In general, the materials used as jewelery in Yogyakarta, especially Kotagede are silver, brass and copper. White tin which is widely available in Indonesia can actually be used as an art product. Craftsmen prefer to use metals, such as silver, copper and brass. Generally, tin is used as a metal connecting material, whereas the white tin can be used as jewelry if mixed with antimony and copper in certain quantities. With a more affordable price, if it has become a well-worked art product, it will open up employment opportunities for the wider community. Direct observation and experimentation are the right methods in designing this product, through stages: a) Surveying, b) Synthesis, c) Design development, d) Evaluation will get comprehensive and near perfect data. Because in that way the community is no longer awkward to use quality pewter. The main reason pewter is attractive is that although the metal is not considered a precious metal, it is mixed with copper and antimony when it is almost the same color as silver. As a jewelry material, pewter has an attractive appearance. With a touch of contemporary design, it will add value to the material.
\end{abstract}

Key Word : design, pewter, jewelry

\section{ABSTRAK}

Pemanfaatan timah putih sebagai kekayaan alam di Indonesia untuk bahan perhiasan belum cukup dikenal. Timah putih yang dicampur dengan logam tembaga dan antimonium ternyata bisa menjadi bahan perhiasan yang menarik secara visual. Secara umum, material yang dipakai sebagai bahan perhiasan di Yogyakarta, khususnya Kotagede adalah perak, kuningan, dan tembaga. Timah putih yang banyak terdapat di Indonesia sebenarnya bisa dimanfaatkan menjadi produk seni. Perajin lebih suka memanfaatkan logam, seperti perak, tembaga, dan kuningan. Umumnya, timah dijadikan bahan penyambung logam, padahal timah putih tersebut bisa dimanfaatkan menjadi bahan perhiasan apabila dicampur antimonium dan tembaga dalam takaran tertentu. Dengan harga yang lebih terjangkau, apabila sudah menjadi produk seni yang digarap dengan baik, akan membuka peluang kerja bagi masyarakat luas. Pengamatan langsung dan eksperimen merupakan metode yang tepat dalam perancangan produk ini, melalui tahapan: a) Survei, b) Sintesis, c) Pengembangan desain, d) Evaluasi akan diperoleh data yang komprehensif dan mendekati sempurna. Sebab dengan cara seperti itu masyarakat tidak canggung lagi untuk menggunakan pewter yang berkualitas. Alasan utama pewter menarik adalah jenis logam tersebut meskipun dianggap bukan jenis logam mulia, namun logam ini apabila dicampur dengan tembaga dan antimon akan memiliki warna yang hampir sama dengan perak. Sebagai material perhiasan, pewter memiliki penampilan yang menarik. Dengan sentuhan desain yang kekinian, akan menambah nilai material tersebut.

Kata Kunci: perancangan, pewter, perhiasan 


\section{PENDAHULUAN}

Di Yogyakarta terdapat berbagai macam produk perhiasan yang terbuat dari perak, hampir $95 \%$ produk perhiasan terpusat di Kotagede dengan berbahan perak 925. Produk kerajinan perak mendominasi pasar perhiasan di Yogyakarta. Hal ini menyebabkan kurangnya diversifikasi material sebagai bahan pembuatan perhiasan, terutama material jenis logam. Semakin mahalnya bahan baku perak menjadi kendala tersendiri bagi para perajin di Kotagede. Banyak pengusaha perak yang mengurangi sejumlah karyawannya karena faktor efisiensi perusahaan. Dipertegas dengan krisis ekonomi global pada tahun 2008 yang sangat terasa dampaknya bagi perajin perak Kotagede (Salim Silver, Hasil Wawancara, 18 Maret 2017). Hal ini tentu berpengaruh terhadap daya beli masyarakat yang lebih memilih perhiasan berbahan logam yang terjangkau bagi kantong mereka.

Fenomena ini bisa dilihat ketika booming batu akik tahun 2014-2015, masyarakat lebih banyak memilih produk emban cincin akik yang bukan terbuat dari perak standar 925. Mereka lebih memilih produk impor dari Cina sebagai pilihan untuk menambah "wah" penampilan. Dengan harga yang terjangkau, emban batu akik dari Cina tampil dengan berbagai macam desain berbahan logam paduan yang relatif murah. Batu akik pun tampil menawan dan terkesan mewah walaupun memakai emban yang bukan terbuat dari bahan logam mulia. Dengan demikian, bisa dilihat selera pasar perhiasan bukan perak masih terbuka lebar. Berkaitan dengan hal tersebut, ditambah Yogyakarta dengan predikat sebagai kota pariwisata dan pendidikan, peluang pasar perhiasan pewter terbuka sangat lebar. Perhiasan berbahan logam pewter mempunyai peluang yang sama dengan perhiasan perak Kotagede. Dengan harga yang terjangkau kantong anak muda dan menawarkan desain yang "kekinian", perhiasan pewter mampu bersaing dengan perhiasan lainnya.

\section{Landasan Perancangan}

Potensi Indonesia dalam usaha di bidang produk perhiasan, khususnya berbasis logam sangat tinggi karena didukung oleh banyaknya sumber daya alam timah. Berdasarkan data terakhir dari Kementerian Perindustrian $\mathrm{RI}$, nilai ekspor produk home decor berbahan kayu pada 2015 tercatat senilai 10,45 triliun rupiah. Menghasilkan devisa sebesar 3,5 miliar dolar AS, salah satu peluang untuk memasarkan produk perhiasan Indonesia disebutkan sebanyak 36.636 perusahaan dan menyerap tenaga kerja sebanyak 43.348 orang. Industri perhiasan mampu memberikan kontribusi signifikan terhadap perekonomian nasional, bahkan sektor yang berbasis IKM ini memiliki potensi dan peluang cukup besar, sehingga diperlukan upaya-upaya terobosan untuk pengembangan produksi dan peningkatan daya saingnya.

Dalam beberapa dekade terakhir, kondisi ekonomi global yang belum stabil, tidak memengaruhi permintaan perhiasan di Indonesia. Bahkan, nilai ekspor komoditas tersebut terus menunjukkan hasil yang positif. Bersamaan dengan meningkatnya industri desain, kebutuhan produk perhiasan dan aksesoris menunjukkan peningkatan aktivitas perdagangan, baik di dalam negeri maupun luar negeri. Para produsen pun tidak sedikit yang sudah sampai pada penggunaan bahan pewter sebab permintaan perhiasan berbahan nonlogam mulia semakin meningkat.

Tujuan ekspor produk perhiasan Indonesia, antara lain ke Singapura, Hongkong, Amerika Serikat, Jepang, Uni Emirat Arab, serta ke berbagai negara Eropa, seperti Inggris, Belanda, Denmark, dan Swedia. Perhiasan berbahan pewter sekilas tidak terlihat adanya perbedaan yang signifikan dengan perhiasan perak karena hampir memiliki penampilan warna yang mirip, sehingga masyarakat banyak yang menyukainya. Di samping harganya lebih terjangkau, kerajinan pewter mampu menjadi sektor unggulan apabila dikelola dengan baik.

Semakin banyaknya perajin yang menekuni bidang aksesoris berbahan logam, dan minimnya desain di dalam mengolah materialnya, persoalan yang perlu segera ditangani adalah sebagai berikut: Bagaimana desain-desain yang bervariatif guna mengolah 
pewter menjadi produk seni dan teknik apa yang digunakan untuk mengolah pewter dalam mewujudkan desain-desain tersebut?

\section{METODE PERANCANGAN}

Metode perancangan dilakukan melalui beberapa tahapan:

\section{a. Tahap Analisis}

Permintaan produk perhiasan Indonesia rata-rata senilai 3,31 miliar USD setiap tahunnya, dengan profit relatif meningkat dari tahun ke tahun. Kementerian Perindustrian telah melakukan berbagai program dan kebijakan strategis. Misalnya, membentuk lembaga sertifikasi yang bertugas memberikan sertifikat terhadap perhiasan Indonesia yang diakui oleh dunia internasional. Kementerian perindustian juga memberikan pelatihan dan pendampingan. Hal demikian bisa diduga kurangnya desain kebaruan. Kriteria pemesanan akhir-akhir ini tidak bisa dipenuhi lantaran terbatasnya produksi dan kesulitan bahan baku. Oleh karenanya, penawaran bahan alternatif harus dilakukan.

Strategi yang perlu dilakukan dalam meningkatkan nilai jual ini antara lain dengan eksplorasi sumber daya lokal dan memasarkan nilai-nilai orisinalitas produk perhiasan Indonesia, serta memastikan ketersediaan yang stabil dan fleksibel, sehingga dapat memenuhi kebutuhan konsumen. Di samping itu, membuat produk yang sifatnya unik, inovatif, dan disesuaikan dengan kebutuhan konsumen. Diharapkan tidak hanya meningkatkan kuantitas penjualan, tetapi juga memberikan keuntungan yang maksimal bagi perancangnya.
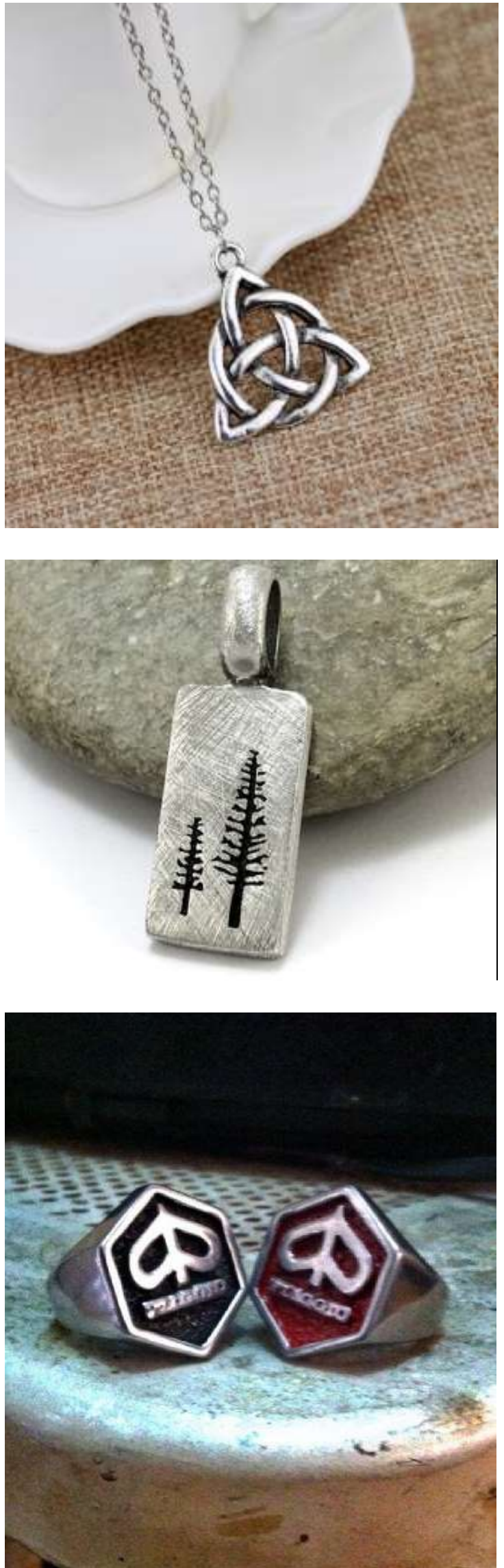


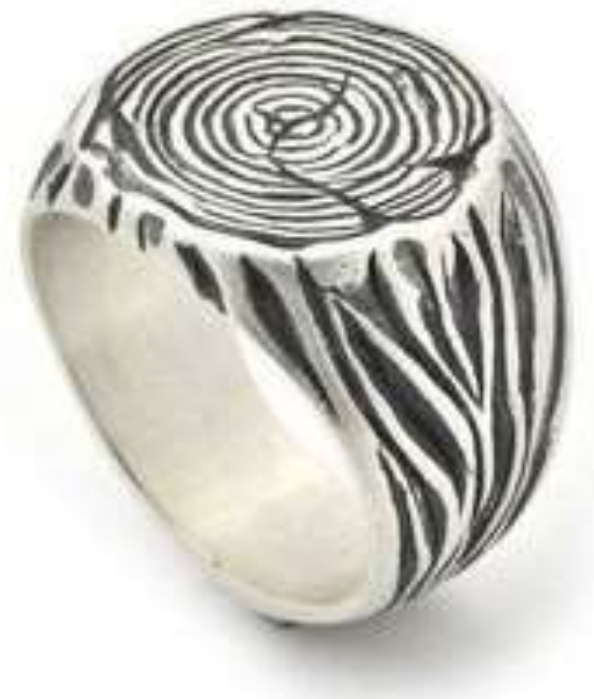

Gambar 1. Acuan Bentuk produk Perhiasan

\section{b. Tahap Sintesis}

Penekanan perancangan untuk menuangkan konsep gagasan dimulai dari deskripsi verbal hasil analisis yang dilakukan ke dalam bentuk visual dua dimensional dan tiga dimensional, meliputi beberapa produk, seperti liontin, bros, cincin, action figure, commercial dinner concept, gelang, giwang, dan cenderamata. Namun demikian, perancangan difokuskan pada produk perhiasan. Penuangan gagasan kreatif menjadi rancangan dua dimensional itu dilakukan dengan pertimbangan berbagai aspek, menyangkut kompleksitas nilai seni kriya, antara lain aspek material, teknik, proses, metode, konstruksi, ergonomi, keamanan, kenyamanan, keselarasan, keseimbangan, bentuk, estetik, gaya, filosofi, pesan, dan makna, berikut fungsi sosial, ekonomi, dan budaya, serta peluang masa depannya.

\section{c. Tahap Evaluasi}

Berawal dari dominasi material pewter sebagai bahan pembuatan produk perhiasan, aksesoris dan sejenisnya menunjukkan bahwa keberadaan logam menempati ranking atas kebutuhan manusia, maka tidak ada salahnya memanfaatkan jenis logam lokal seperti pewter. Di samping melimpah di negeri sendiri, timah putih sebagai campuran penting logam paduan pewter memiliki fitur karakter warna yang kuat, yakni warna yang elegan meskipun tanpa ornamentasi, sehingga lebih mudah dirawat dan harmonis jika dipadukan dengan produk lainnya.

Langkah selanjutnya ialah visualisasi gagasan dari rancangan sketsa alternatif terpilih atau gambar teknik yang telah dipersiapkan menjadi suatu bentuk model prototipe. Pembuatan model prototipe ini dibangun berdasar butir penting hasil analisis dan tahap sintesis yang berhasil dirumuskan, atau berdasarkan gambar teknik yang telah disiapkan. Penyajiannya berdasarkan proses pembentukan karya seni yang berlaku, yaitu berdasarkan gambar teknik berikut detail kelengkapannya, atau berdasarkan model prototipe tadi.

\section{d. Tahap Pengembangan Desain}

Pengembangan desain dilakukan berdasarkan tahapan: 1. Observasi untuk melihat perbandingan desain dan produk yang sudah ada, sehingga akan muncul deskripsi persoalan yang harus dipecahkan, 2. Melakukan evaluasi atau analisis menggunakan analisis SWOT, 3. Proses pembuatan sketsa-sketsa alternatif, 4. Proses perancangan, dan 5. Penyajian dan evaluasi. Produk yang akan dibuat meliputi commercial jewellery.

\section{Gagasan Pemecahan masalah}

Hasil rancangan desain yang dilakukan oleh perajin perak Kotagede, yaitu Priyo Salim, telah menghasilkan produk-produk aksesoris perhiasan perak, seperti cincin, gelang, liontin, dan bros. Berbagai desain yang dirancang kemudian ditawarkan kepada publik dalam negeri maupun mancanegara. Kesimpulannya bahwa desain-desain rancangannya tersebut mampu mewujudkan produk yang digemari konsumen dalam negeri maupun mancanegara.

Mayoritas rancangan mereka menggunakan elemen ukiran klasik Jawa. Pandangan para desainer mengenai ukiran klasik di masa lalu cenderung dimunculkan kembali di masa kini meskipun terkadang menjadi perdebatan yang menarik mengenai perlu tidaknya suatu produk memiliki ornamen ukiran. Memang tidak mengharuskan bahwa sebuah produk harus menyertakan ornamen ukiran, maka 
sebetulnya apa tujuan dan bagaimana penempatannya? Pertanyaan seperti itu memberikan tantangan baru bagi rancangan produk yang kami buat, yakni meskipun tidak memerlukan ukiran namun perlu disesuai dengan kebutuhan masa kini dan tidak lepas dari prinsip-prinsip seni rupa.
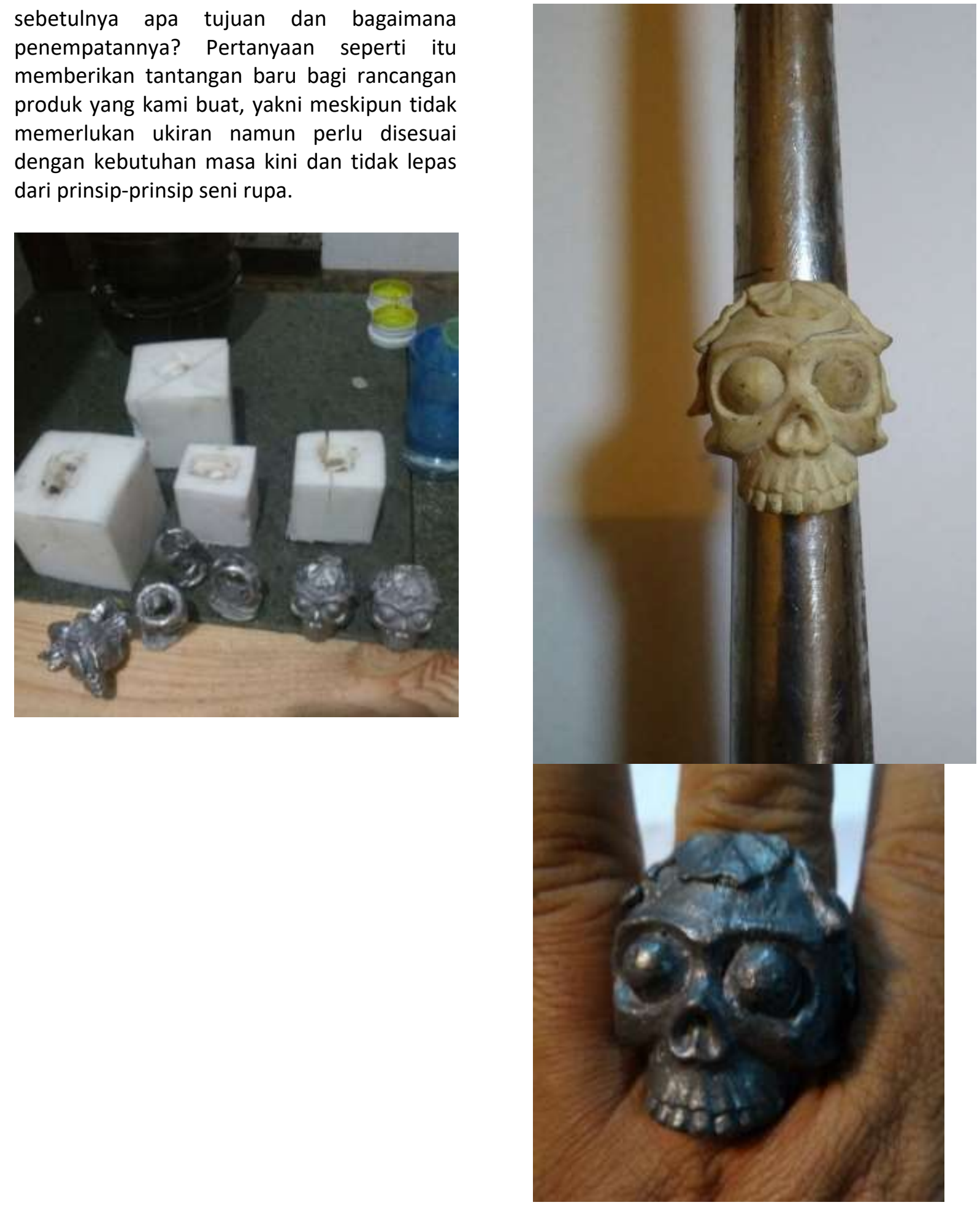

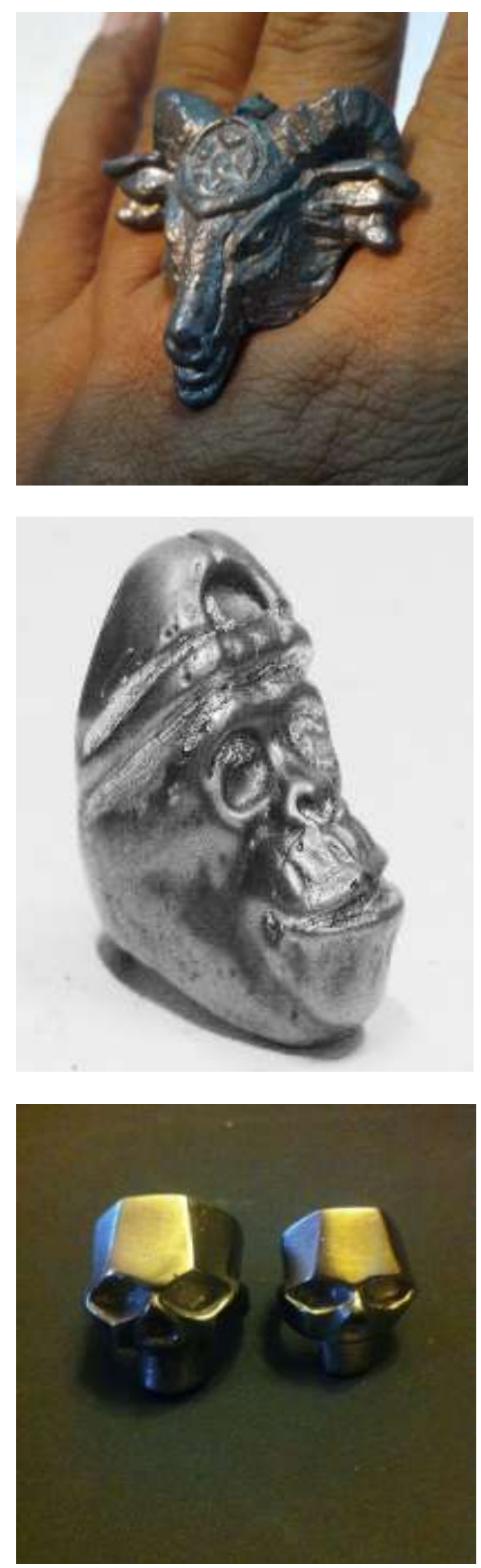

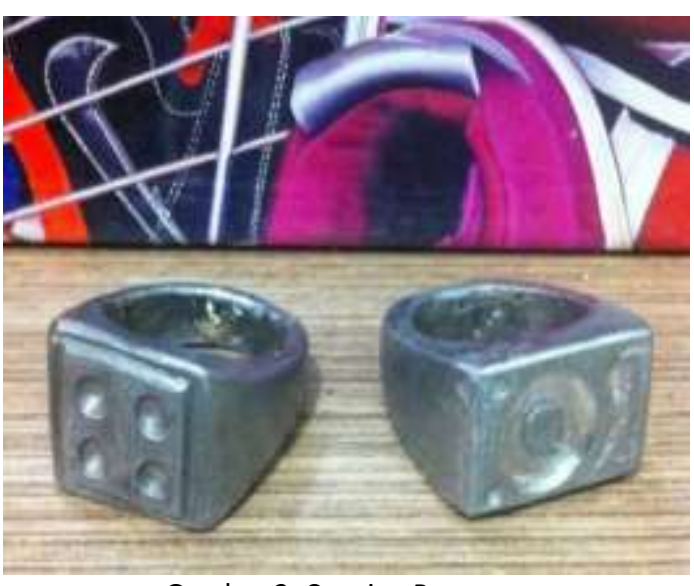

Gambar 2. Capaian Perancngan

\section{PENUTUP}

Ketika produk keperluan menghias tubuh mulai berkembang, apa yang disebut dengan perhiasan tidak lagi menjadi heran bagi kalangan masyarakat Indonesia, apalagi di kalangan generasi muda. Sebab, kata perhiasan berkembang dalam kondisi tidak terbatas dan jauh melalui teknologi modern. Namun demikian, pemilihan material tetap bisa diupayakan terobosan-terobosannya dan dikembangkan dengan mengedepankan bobot seni dan keindahan, bahkan bisa menempati fungsi-fungsi bagi keperluan masyarakat. Perhiasan sekarang sudah sangat maju dari segi material, teknik pengerjaan, ataupun desainnya merupakan terobosan kreativitas yang tidak terbatas dalam bereksplorasi.

Dapat disimpulkan bahwa peneliti ataupun para perancang sebelumnya banyak membicarakan wilayah ornamen dan mengabaikan material yang digunakan sebagai media cipta. Mungkin mereka beranggapan bahwa bahan logam selama ini tidaklah menjadi persoalan, sebab Indonesia kaya akan bermacam-macam logam berkualitas bagus, terutama logam mulia. Bahkan, mereka tidak sampai pada pemikiran untuk memadukan logam timah, antimonium, tembaga yang dinamakan pewter sebagai bahan alternatif membuat perhiasan pewter.

Oleh karena itu, perancangan ini memaksimalkan logam lokal asli Indonesia yang banyak terdapat di Bangka Belitung, yaitu timah putih sebagai bahan utama pembuatan logam pewter. Produknya pun 
tidak sebatas perhiasan yang dikenakan di tubuh, atau produk-produk yang sudah berkembang di masa kini, tetapi bisa melampaui itu. Dengan kata lain, produk perhiasan pewter menawarkan kekinian dan keunikan.

\section{DAFTAR PUSTAKA}

Gunawan, Solichin. "Desain di Indonesia." Majalah POLA. 23 Oktober 1977. Bandung ITB.

Nova. "Rangkaian Kerang nan Cantik." Majalah Handi Craft. Edisi 18 AprilMei 2005. Yogyakarta.

Salim Silver. 2017. Hasil Wawancara dengan Para Perajin Perak Kotagede. 18 Maret 2017.

Soehadji, M. Art and Craft Movement,

(terjemahan). STSRI "ASRI"

Yogyakarta.

Gustami, SP. 2006. "Trilogi Keseimbangan Ide Dasar Penciptaan Seni Kriya: Untaian Metodologis." Naskah Publikasi. ISI Yogyakarta. 